\title{
Att vara pappa i homofamiljer- berättelser om barn, mammor och familjeliv
}

\section{KARIN ZETTERQVIST NELSON}

Den här artikeln handlar om faderskapets betydelse och utformning i planerade homosexuella familjer, s. $k$. regnbågsfamiljer. Två skilda sätt att tala om rollen som pappa har kunnat urskiljas. I båda sätten bryter man mot den heteronormativitet som genomsyrar familje- och föräldradiskurser, där föräldraskap ses som en konsekvens av heterosexuell tvåsamhet. Vad som skiljer demåt är $i$ vad mån man utmanar den genusordning som reglerar synen på kvinnligt och manligt i relation till föräldraskap.

\section{Bakgrund och syfte}

Ett viktigt kännetecken för planerade homosexuella familjer, s.k. regnbågsfamiljer, är att den person eller det par som vill ha barn har involverat en tredje part, antingen en person/ett par för privat insemination eller en adoptivorganisation för adoption. ${ }^{1}$

Karin Zetterqvist Nelson är lektor i psykologi vid Institutionen för beteendevetenskap, Linköpings universitet. Hon är involverad i forskningsprojekt vid både IBV och tema Barn, Linköpings universitet.
Lesbiska par har möjlighet att vända sig till fertilitetsklinik. Det innebär att regnbågsfamiljer får olika utformning, beroende på vilka val man gjort. Här finns ensamstående föräldrar, två-föräldrakonstellationer, liksom familjer med tre eller fyra föräldrar, som i likhet med det länkade familjesystemet (Larsson Sjöberg 2000) kännetecknas

1 Att beteckna sig som regnbågsfamilj signalerar både en koppling till den homosexuella rörelsen och variationen i familjeformer. 
av att barnen delar sin tid mellan två hushåll. Regnbågsfamiljerna är exempel på moderna nätverksfamiljer (Bäck-Wiklund 2003), det reflexiva projektet "par excellence» (Dunne 2000, se också Castells 1997, Giddens 1995). Men det finns också något särskilt med regnbågsfamiljer, nämligen föräldrarnas sexuella orientering. Den har inte betydelse i utövandet av föräldraskap, vilket har påvisats i en rad studier (för översikt Anderssen et al. 2002, Stacey \& Biblarz 2001, SOU 2001:10). Däremot har den betydelse såtillvida att regnbågsfamiljer befinner sig i ett samhälle, inte bara dominerat av heterosexuella. Det är ett samhälle genomsyrat av heteronormativitet, som får heterosexuella relationer att framstå som de självklart naturliga och homosexuella som främmande, annorlunda och avvikande (Kulick 2005). Regnbågsfamiljer har med andra ord skapat sig ett utrymme mot alla odds. Trots ett ökat rättsligt stöd för homosexuellas familjebildning, genom partnerskapslagen (SFS 1994:1117) utgör dessa familjers existens och berättade erfarenheter en samhällelig, social och psykologisk utmaning. ${ }^{2}$

I den här artikeln ska faderskapets betydelse och utformning diskuteras. Tolv homosexuella fäder och deras berättelser om att få barn och att bli pappa står i fokus. Det övergripande syftet är att skapa en förståelse för faderskapets innebörder utifrån

2 Idag omfattar partnerskapslagen också möjligheten för registrerade partners att bli prövade som adoptivföräldrar (sedan den 1 februari 2003), liksom möjligheten för lesbiska partners att få tillgång till assisterad befruktning på fertilitetskliniker (sedan 1 juli 2005). hur papporna själva talar om familjen och sin betydelse för både barnen och övriga föräldrar. Centralt i den narrativa analysen är den tid i familjens liv då ett delat föräldraskap konkretiseras i ett vardagsliv. Datamaterialet utgör en del av en mer omfattande studie av homosexuella familjer med barn som genomfördes under 2002-2003. Den presenteras senare i artikeln. ${ }^{3}$

\section{Tidigare forskning}

Homosexuellt faderskap är till stora delar ett outforskat område, vilket delvis reflekterar en generell obalans mellan studier av moderskap och studier av faderskap. Forskningen om faderskap har dock expanderat (Plantin 2003), från ett ensidigt intresse riktat mot de situationer där faderskapet definieras som bristfälligt till en ökad uppmärksamhet på fäders delaktighet i vård och omsorg (se t.ex. Bekkengen 2002, Berg \& Johansson 1999, Hagström 1999, Klint 2002). Homosexuellt faderskap har börjat ta plats på detta fält (Johansson 2004).

I psykologisk forskning om homosexuellt föräldraskap har faderskapet fokuserats, även om lesbiska mödrar fått mer uppmärksamhet. Kunskapsintresset har varit inriktat på hur barns psykosexuella utveckling påverkats av homosexuella fäder, liksom hur relationen till barnen påverkats av att pappan kommit ut som homosexuell för barnen (Bozett 1980, 1988, 1993). Vid en jämförelse med lesbiska mödrar visar det

3 Studien genomfördes tillsammans med professor Margareta Hydén och är finansierad av FAS. 
sig att fäderna tar längre tid på sig i denna process (Wyers 1987). Bortsett från ett fåtal kvantitativt inriktade studier (se t.ex. Bailey et al. 1995, Crosbie-Burnett \& Helmbrecht 1993), består forskningsfältet till största del av kvalitativa studier, ofta med socialpsykologisk/sociologisk inriktning (se t.ex. Mallon 2004, Weeks et al. 2001).

De brittiska familjeforskarna Helen Barrett och Fiona Tasker genomförde i början av 2000-talet en omfattande enkätstudie i syfte att kartlägga omfattning och utformning av homosexuellt faderskap. Resultaten påvisar ett mycket diversifierat föräldraskap, där de flesta fäder fått barn i heterosexuella relationer. Andra vägar till föräldraskap var att ha fosterbarn eller via adoption. En ringa del av antalet tillfrågade utgjordes av fäder som fått barn via privat insemination (Barrett \& Tasker 2001). En studie av explorativ karaktär av "gay fathers" har genomförts av den brittiska sociologen Gillian Dunne (2001). Dunne hävdar att de erfarenheter hon tar del av visar hur föräldraskap i de homosexuella familjebildningarna organiseras på nya och oväntade sätt. Problemet med studien är att störst utrymme i artikeln ges de fäder som fått barn via heterosexuella relationer, medan de planerade homosexuella familjerna diskuteras mycket tentativt. I en genomgång av forskningsområdet påpekas just bristen på studier av fäder i planerade homosexuella familjer (Armesto 2002). Ett undantag är en relativt ny norsk studie om faderskap (Andersen 2003). I den fokuseras dels heterosexuella "deltidspappor", dels homosexuella fäder som har barn med lesbiska par. Gemensamt för dessa båda grupper är att föräldraskapet inte utformas av ett heterosexuellt par i ett gemensamt rum, vilket bryter den kulturella heteronormativiten. I studien framgår att barnen till de homosexuella männen spenderar största delen av sin tid i mödrarnas hem. Specifikt för dessa fäders situation är att föräldraskapet byggs upp på en vänskapsrelation. En traditionell arbetsdelning verkar dock upprätthållas, som en upprepning av en genusordning där kvinnor spenderar mest tid med barnen. De fåtal fäder som ingår presenteras mer som enskilda fall, med fokus på faderskapets rumsliga dimension, varvid fynd av mer generell karaktär inte diskuteras explicit.

Faderskapets betydelse har belysts i studier av lesbiska pars familjebildning, där donatorns roll i den blivande familjen fokuserats; som anonym donator eller som en aktiv pappa/förälder delaktig i omsorg och uppfostran (se t.ex. Nelson 1996, Donovan 2000, Touroni \& Coyle 2002). En viktig studie i sammanhanget är genomförd av sociologen Róisin Ryan-Flood (2005), i vilken hon jämför utformandet av lesbiskt moderskap i Sverige och Irland. ${ }^{4}$ Den skillnad som framträder knyter Ryan-Flood till skilda välfärdsstrategier på familjepolitikens område. Synen på den biologiska pappans roll för barnet, liksom politiska kampanjer för ett jämställt föräldraskap, som att uppmuntra pappaledigheter, framträder i de svenska lesbiska kvinnornas sätt att tala om donatorer och faderskap. De betonar i högre omfattning vikten av att involvera donatorn i familjen, inte bara för att barnen ska känna till sitt biologiska ursprung, utan som relaterande pappor och manliga före-

4 Återfinns i svensk översättning i Kulick (2005). 
bilder. Mot den bakgrunden betonar RyanFlood vikten av att se heteronormativitet som kontextuell och varierad i sin utformning (Ryan-Flood 2005).

I dessa studier är det dock mödrarna och deras uppfattningar och resonemang om fädernas/donatorernas roll som står i centrum. Med andra ord, faderskapets innebörder i planerade homosexuella familjer har hittills främst studerats utifrån mammornas perspektiv. Pappornas perspektiv är fortfarande till stor del frånvarande på forskningsområdet. Den här artikeln innebär därmed ett utvidgat perspektiv på frågan om faderskapets betydelse i dessa familjer. Det är pappornas berättelser om att bilda och göra regnbågsfamiljer som skall belysas.

\section{Studien}

Den här studien påbörjades under 2002 och material samlades in under 2002-2003. Forskningsprojektets övergripande syfte är att bredda och fördjupa förståelsen av de villkor och relationer som präglar svenska homosexuella familjer med barn som planerats och tillkommit $i$ en homosexuell relation. För att knyta kontakt med berörda familjer och föräldrar kontaktades organisationen Regnbågsföräldrar, en stödorganisation för omkring 400 homosexuella föräldrapar. Projektidén presenterades också i tidningen Kom Ut, utgiven av RFSL. Projektet mottogs positivt och i samband med dessa kontakter utvecklades och förankrades metodologin på ett gynnsamt sätt.

Urvalet av deltagare i projektet genomfördes i två steg. För att kartlägga vilka olika familjeformer som förekommer, utformades en enkät med frågor om föräldrar, barnens tillkomstsätt och ålder som distribuerades med hjälp av ansvariga för nätverket. Till enkäten bifogades information om projektet i sin helhet, samt förfrågan om att ställa upp som intervjuperson. 57 homosexuella föräldrar med 74 barn i åldrarna 0-13 år fyllde i en enkät med frågor om familjestruktur. 26 uppgav att de var villiga att bli intervjuade. I denna grupp av 26 föräldrapar respektive ensamstående, bildade några en gemensam länkad familj, varvid studien totalt kom att omfatta 20 familjer. De var bosatta över hela landet, främst i storstadsområdena. Intervjuerna var semistrukturerade och utformade för att gynna framväxten av personliga berättelser. Intervjuguiden bestod av tre centrala frågeområden: 1) Vad är en familj? 2) Berätta om din familj! Hur kom den här familjen till? 3) Vad är fördelar och nackdelar med en familj som er familj? Intervjuerna kom att bli reflekterande samtal, med långa och detaljerade berättelser om familj och familjeliv. När föräldraskapet delades av ett par som bodde ihop, intervjuades dessa tillsammans. När det rörde sig om en förälder, som delade föräldraskap med ett annat par, intervjuades den förre själv. Intervjuerna genomfördes $i$ informanternas hem, och transkriberades sedan i sin helhet, totalt 533 sidor.

\section{Informanterna}

De pappor som ingår i intervjustudien är totalt 14 till antalet (se Tabell 1). I denna 
artikel är det papporna som skaffat barn tillsammans med en eller två kvinnor som står i förgrunden. Det är dynamiken mellan de involverade föräldrarna och barnen, såsom den beskrivs av papporna, som är av intresse. Det par som adopterat har därför uteslutits, varvid tolv fäder står i centrum här. Sex av dessa tolv informanter utgörs av tre par, som vart och ett delar föräldraskap med ett lesbiskt par. De övriga sex männen är ensamstående pappor, varav tre lever själva och tre är sammanboende (med män som inte varit delaktig i tillkomsten av familjen). De pappor som ingår i studien har genomgående en akademisk utbildningsbakgrund (med yrken som socionom, läkare, journalist, och ingenjör). Barnen till fäderna varierar $\mathrm{i}$ ålder, alltifrån spädbarn till 13 år. ${ }^{5}$ Namnen är fingerade.

5 Barnens ålder, liksom fädernas utbildningsbakgrund anges för att ge en bild av informantgruppen.
I intervjuerna beskrivs tre olika tillvägagångssätt att bli pappa som homosexuell man. Ett sätt att skaffa barn är via adoption, vilket enbart ett av de manliga paren valt. Ett annat är att tillfråga en kvinna om ett delat föräldraskap. Då söker man en föräldrapartner via annonser eller via bekanta och vänner, ett tillvägagångssätt som beskrevs av åtta av de intervjuade. ${ }^{6}$ En tredje väg till faderskap är att själv bli tillfrågad om att bli pappa av antingen ett lesbiskt par eller lesbisk ensamstående kvinna, vilket beskrevs av fyra av de intervjuade.

\section{Analys avintervjuerna}

När papporna började tala om sina familjer skapades berättelser om en lång och utdra-

6 I intervjuerna framkom att ett flertal använt olika sökvägar innan man hittat en föräldrapartner.

Tabell I.

\begin{tabular}{|c|c|c|c|c|}
\hline Informanter & Adoptivföräldrar & $\begin{array}{l}\text { Delar föräldraskap } \\
\text { med en kvinna }\end{array}$ & $\begin{array}{l}\text { Delar föräldraskap } \\
\text { med två kvinnor }\end{array}$ & Antal barn \\
\hline Per & & $x$ & & 2 \\
\hline Jonas & & & $x$ & । \\
\hline Anders & & & $x$ & 3 \\
\hline Roland & & & $x$ & 3 \\
\hline Bengt & & & $x$ & I \\
\hline Bertil & & & $x$ & 2 \\
\hline Olle \& Mikael & & & $x$ & I \\
\hline Jan \& Peter & & & $x$ & 2 \\
\hline Oskar \& Bo & & & $x$ & 2 \\
\hline N\&N* & $x$ & & & I \\
\hline
\end{tabular}

*Adoptivföräldrarna ingår inte i denna artikel. 
gen väg till att bli en familj. Här återfinns beskrivningar om komplicerade beslutsprocesser, om att skaffa barn via privat insemination, om graviditetsperioder, förlossning och spädbarn. ${ }^{7}$ Liksom om föräldrarnas förhandlingar rörande umgänge, övernattningar och barns boendesituation.

Vid de första genomläsningarna av dessa intervjuberättelser framträdde olika sätt att tala om sig själv som pappa. Mot den bakgrunden genomfördes en systematisk analys, som ursprungligen är utvecklad av Michael Bamberg (2004). Bamberg använder begreppet "positionering" som en utgångspunkt för en diskussion om hur identitet skapas och omskapas i berättandet. ${ }^{8}$ I analysprocessen särskiljs tre nivåer.

På den första nivån analyseras berättarens sätt att tala om andra viktiga personer och hur de relateras till berättaren själv. Bamberg sammanfattar denna med frågan: "Who Are the Characters and How Are They Positioned in the Story?» (ibid. s. 340). I detta sammanhang innebär det ett fokus på pappornas sätt att tala om sig själva, både i relation till barnen och mammorna. På nivå två är det talet-i-interaktion som fokuseras, vilket innebär en uppmärksamhet på interaktionen med både intervjuaren och en tänkt publik utanför intervjusituationen. Bambergs fråga för denna nivå är: "How Does the Speaker/Narrator Position Himself vis-à-vis His Interlocutors?" (ibid. s. 343). Skiftet till en tredje nivå innebär att berättandet relateras till sitt samhäl-

7 Berättelser om beslut att försöka få barn har analyserats i Zetterqvist Nelson (in press).

8 Michael Bamberg är disciplinmässigt förankrad i narrativ- och diskursiv psykologi. leliga, kulturella och historiska sammanhang. Då åsyftas den knytning som finns till "dominerande diskurser", "stora berättelser" eller "kulturellt tillgängliga berättelser». Hur förhåller sig berättaren till dessa och vad i berättandet kan vi känna igen som del av samhälleligt kontext. Med Bambergs egna ord, intresset på denna nivå riktas mot "Positions Taken vis-à-vis Normative Discourses and 'Self" " (ibid. s. 347). I detta sammanhang innebär det att pappornas berättande relateras till samhälleliga diskurser om att vara pappa och om faderskapets innebörder, i en nutida svensk kontext.

Analysen visar på två olika sätt att förhålla sig till faderskapet, som konkret yttrar sig i två olika sätt att prata om och beskriva sig själv som pappa och sitt faderskap. Jag ser dessa som två alternativa sätt att förhålla sig till faderskapet och att forma en pappaidentitet, som är knutna till tid och plats. De bör inte förväxlas med en kategorisering på gruppnivå, det rör sig inte om olika slags pappor, utan om identiteter och förhållningssätt som är knutna till olika tidpunkter och sammanhang. I följande två avsnitt presenteras vart och ett av dessa sätt att prata om sig själv som pappa.

\section{En pappa som anpassar sig till mamma}

Det förhållningssätt till faderskapet som ska diskuteras först karaktäriseras av att mammorna tillskrivs företräde $\mathrm{i}$ frågor som rör vård och omsorg om barnen. Sammantaget är det fyra informanter, var och en ensamstående som pappa, som i olika 
sammanhang uttrycker detta i och genom sitt berättande. Deras barn varierar i ålder, alltifrån tre till tolv år.

Ett sammanhang där detta förhållningssätt blir tydligt är när informanterna talar om mammornas hem. Termen »bas« används av flera av dem när man talar om mammornas hushåll. När Anders, pappa till tre barn beskriver barnens boendesituation säger han: "Dom har basen hemma hos Johanna... de var ju hemma hos Fia och Johanna för där har de varit hela tiden... basen."

Men det är inte bara mammornas hem som tillskrivs särskild vikt, utan mammorna tillskrivs särskild betydelse för barnen. I intervjun med Anders framgår det när han berättar om familjens julfirande. Intervjuaren frågar mer specifikt om hur barnen relaterar till föräldrarna när alla fyra är närvarande:

Intervjuare När hela familjen är tillsammans med barnen [...] vad gör barnen $i$ det här... delar dom lika uppmärksamhet med alla eller har dom liksom?

Anders Alltså dom har ju fyra vuxna och det har väl varit lite olika... den dom har tytt sig till... mamma är ju alltid mamma... det är väl alltid den viktigaste personen $i$ alla fall när dom är så där små... så det liksom vet domju

På intervjuarens fråga svarar Anders först att "det har väl varit lite olika", men övergår sedan till att prata om vem barnen har "har tytt sig till». Då använder han uttrycket "mamma är ju alltid mamma", förstärkt i nästa mening med att mamman som "alltid den viktigaste personen". Det går att tolka som uttryck för ett accepterande av mammans företräde, något som enligt Anders barnen "vet». Sedan lägger han till att mamman är viktigast "i alla fall när dom är så där små...", vilket antyder hur förhållanden förändras i och med barnen växer och blir större. Här skapas en bild av mammans företräde som förälder till barnen, i alla fall när det gäller yngre barn.

I Jonas redogörelse av sin familj framträder en liknande bild, med tillägg att hans roll som pappa skiljer sig från mödrarnas. På uppmaning från intervjuaren att berätta om sin familj säger Jonas:

Jonas

Ja min familj... dom som ingår $i$ den är ju då förutom Lena (mamma) mitt barn... hon bor ju hos Lena och Tove (mamma) och det är där också dom har vårdnaden... så det är dom som har den huvudsakliga fostran och ansvaret... jag är mer den som försöker hitta en annan roll än den vardaglige vuxengestalten i hennes (dotterns) vardagsliv

Jonas pratar om mammorna i termer av "dom har vairdnaden", vilket innebär att de har "den huvudsakliga fostran och ansvaret». Sedan fortsätter han att prata om sig själv, i relation till mammorna, som att jag "försöker hitta en annan roll än den vardagliga vuxengestalten". När han ombeds utveckla sig kring denna skillnad mellan föräldrarollerna säger han: 
Jonas

Men båda två är väldigt mammiga... och så tänkte jag att gud... det är verkligen viktigt att hon (dottern) har en pappa... för jag känner desto större krav av att vi måste hoppa bungy-jump och cykla mountaincycle så hon fär lite äventyr... såna farliga saker som papporna tycker om

Pappans roll mejslas ut med hjälp av ord som "äventyr" och "farliga saker", medan mammorna beskrivs av Jonas med ord som "ansvar" och "vårdnad".

Detta sätt att positionera sig som pappa, där mammorna tillskrivs en primär roll för barnen, omfattar också ett särskilt sätt att beskriva relationen till barnen. Här formas bilden av en relation som utvecklas med tiden. Per, pappa till två barn, berättar om när barnen var nyfödda, och bodde hemma hos mamman, och den känsla av vanmakt han upplevde när han skulle ta hand om barnet.

Per

Den här fullständiga vanmakten (Intervjuare: Ja) det här är inget barn jag hailler $i$ min hand... det är en massa skrikande alien som är fullständigt okontaktbar... ӓӓӓӓӓӓӓӓ̈̈а... vad gör man... upp och ner... va sjutton vanka där.. vad händer... fast det tror jag inte är nåt unikt för homofamiljer... utan det är nog en manlig erfarenhet... trorjag

Relationen mellan honom och barnen som spädbarn framställs inte som något självklart, utan snarare som en känsla av främlingskap och vanmakt: "en massa skrikande alien«. I detta sammanhang orienterar han sig också mot samtalssituationen - han hävdar att denna erfarenhet inte är unik i relation till homofamiljer - som en replik till forskningsprojektet. Per säger, med viss försiktighet, att "det är nog en manlig erfarenhet... tror jag". Pappaskapet beskrivs som en relation som inte är given på förhand, utan här finns ett främlingskap som övervinns i det sociala samspelet. Per berättar om sitt halvår som pappaledig, när han tog hand om barnen, i mammans hem, när mamman återgick till sitt arbete. Intervjuaren frågar:

Intervjuare Vad betydde det för dig då det här halvåret?

Per Ja det var jätteroligt...det var det faktiskt... oerhört kul... det var det

Intervjuare Det var det.... hmhm

Per $\quad$ Och det var ju då... som växa till sig... det var ju inte det där monstret (Intervjuare: skrikande alien) inte alien (Intervjuare: neej) det blev litet mer människa på nåt sätt

Spädbarnet förvandlas från att ha varit "den där monster" till att bli "mer människa", säger Per, vilket kan tolkas som en bild av hur relationen skapas och växer fram mellan honom och barnen, under den tid han spenderar som den dagliga vårdaren. Det påminner om hur etnologen Charlotte Hagström beskriver pappablivandet som ».. mannens egen upplevelse av att bli förälder 
och de processer och händelser han själv menar är av betydelse för detta" (Hagström 1999 s. 159). Pappablivandet är, liksom samhällets bekräftande av faderskapet, en process som bygger på "konkreta och symboliska handlingar för att bekräfta och markera statusförändringen" (ibid. s. 159).

Bland dessa fyra fäder skapas en bild av faderskap som anpassats till moderskapet, där mödrarna positioneras som primära $\mathrm{i}$ relation till barnen medan pappornas relation till barnen byggs upp i aktiviteter och socialt samspel. Här uttrycker man också, i olika grad, en skillnad mellan faderskap och moderskap.

Tiden med barnen är ett tema som återkommer i pappornas berättande om sina familjer och relationen till barnen beskrivs som en konsekvens av den tid man spenderar med dem. Det är en tid som dock inte kan tas för given, utan det rör sig om en tid som måste förhandlas med mammorna. Antingen för att man har sin tid med barnen på en plats som inte är ens egen (i mammornas hem), eller för att den tid man har med barnen är reglerad av mammorna. Det går att urskilja viss kritik mot detta förhållande, en kritik som dock uttrycks i mycket försiktiga ordalag.

\section{Enförsiktigkritik}

Kritiken blir synlig i intervjusamtalet via den positionering som åstadkoms i interaktionen med intervjuaren. I intervjun med Roland, en pappa till tre barn, berättar han om tiden då barnen var nyfödda, och beskriver hur han tog ett stort ansvar i vården av barnen. Men han säger att det har skett på de villkor som mammorna ställt upp, vilket han och hans partner accepterade. Det innebar bl.a. att barnens bas var mammornas hem, vilket i sin tur medförde att papporna förväntades ta hand om och vara med sina spädbarn i mammornas hem.

Roland

Ja... det var väl en grej $i$ och för sig då... den är väl också en ganska stor att till slut tyckte jag... det var faktiskt ganska påfrestande och va hemma hos dom så mycket (Intervjuare: Ja... det förstår jag) hemma hos dom liksom

Intervjuare Ibörjan när barnen var små så Roland

Jaa... det var ju ganska många år... det var påfrestande... mer eller mindre för att man inte fick nån egen plats (Intervjuare: Neej) jag är väldigt hemmakär så det var en tung period

Att ta hand om barnen i mammornas hem beskrivs som "påarrestande", han fick inte en "egen plats", vilket innebar att den första tiden med barnen, när de var spädbarn, blev en stung period«. Men det är också allt som sägs, Roland yppar inget som skulle kunna uppfattas som en kritik av detta faktum, utan stannar vid detta slags beklagande av situationen.

Ett annat exempel på hur situationen som pappa beskrivs i problematiska termer, utan att formulera en kritik av att mammorna ställer villkoren, visar sig i Jonas berättande. Först berättar han om tiden som nybliven pappa som präglad av en "overklighetskänslau, eftersom han bara 
träffade barnet var tredje eller fjärde vecka.

Det innebar att hans vardagliga liv, varken privat eller som yrkesmänniska, påverkades av att bli pappa. Men i omedelbar anslutning till detta fortsätter Jonas tala om hur han idag, när hon är två år, skulle vilja träffa sin dotter mer på egen hand, eftersom hon nu både kan prata och gå själv. Beskrivning inleds med att han berättar om sitt stora förtroende för mammorna, på ett sätt som kan tolkas som en försäkran mot att framstå som alltför kritisk.

Jonas Jag har alltid haft hemskt förtroende för dom alltså som föräldrar... mammorna (Intervjuare: Du har liksom ja...) och vi har vetat om vaira roller... och jag var ju rätt så ... trygg vid det

Intervjuare Ja... det är intressant

Jonas Det...kanske... det ärpåsenare tid som jag velat fokusera mer på att... att det här steget som nu är taget... att jag skall få ha Lina (dottern) för mig själv... det kom ju rätt så sent... det kom ju nu alltså på hösten när hon är drygt två år

Intervjuare $\ddot{A} r$ det nåt som du fätt kämpa för tycker du litet eller?

Jonas Joo... dom har (Intervjuare: Okej) dom... kämpa är kanske felord... men mammorna... har vetat om att dom är oroliga till naturen... dom oroar sig som mammor gör... och det blir inte lättare med två (skratt) så att det har varit en process för dom... för dom har heller inte lämnat bort Lina till släktingar eller så... som man kan göra... (Intervjuare: Ja just det) som jag... jag fick ha min guddotter... när hon var två år så då blev hon lämnad här en dag för att jag skulle... en natt så... men mitt eget barn så att säga har jag inte fätt ha hos mig själv senare... så på det viset är det litet konstigt... men det har varit ändå en vilja från deras sida verkligen att få till till stånd det här nu

Efter att Jonas har beskrivit hur han har förtroende för mammorna och hur deras relation har en given karaktär wvi har vetat om våra roller", övergår Jonas sedan i sin andra replik att försiktigt uttrycka hur han skulle vilja träffa dottern lite mer. Det framgår att det finns frågor där parterna inte är överens. Men när intervjuaren använder termen »kämpa för ", avvärjer sig Jonas, »kämpa är kanske fel ord", varvid han tonar ned en eventuell kritik med att säga att mammorna är »oroliga till naturen... dom oroar sig som mammor gör... och det blir inte lättare med två«. Genom att tala om dem i termer av hur mödrar är - »oroliga av naturen" -, liksom det faktum att de är två, framställer han sin belägenhet som en naturlig följd av detta. Men sedan följer en kort berättelse som andas en försiktig kritik av förhållandet. Först säger han att mammorna inte lämnat bort barnet över huvud taget, "som man kan göra", sedan fortsätter han att beskriva hur han har fått ta hand om sin guddotter (som är två år), något han inte fått göra med "mitt eget barn". Därmed framställs relatio- 
nen till dottern som annorlunda, jämfört med relationen till guddottern. I uttrycket "lite konstigt" anar vi en försiktig kritik, men den tonas omedelbart ned av att han betonar att mammornas "vilja» alltid varit att han ska ta hand om barnet.

Jonas berättelse om hur han får träffa sitt gudbarn mer än sin dotter präglas av en positionering där mammorna accepteras som primära i relation till barnet, och att hans roll som pappa innebär en distans, både rumsligt och över tid, till barnet. Liksom att den kritik Jonas uttrycker över detta förhållande, i intervjusituationen blir framställd i mycket försiktiga ordalag. Den lindas in, tonas ned och balanseras med beröm och försäkran om en positiv relation till mammorna. Positioneringen i intervjusamtalet, att man inte vill framstå som kritisk mot mammorna, förstärker därmed bilden av ett förhållningssätt där mammorna ses som primära som föräldrar.

\section{Ett traditionellt faderskapi nyform}

Den pappaidentitet som skapas i det sätt varpå dessa fyra män positionerar sig själva, både i berättelsen om sin familj och $\mathrm{i}$ intervjusituationen, knyter an till en socialt och kulturellt förankrad diskurs om mamman och pappan som bärare av psykologiskt skilda roller. Kvinnan har i kraft av sitt moderskap ett starkt band till barnen. Medan mannen/fadern är mer distanserad från barnen, en symbol för världen utanför, vars relation till barnen utvecklas i socialt samspel med det växande barnet. I detta sätt att positionera sig, och identifiera sig, skön- jer man »den stora berättelsen» om kärnfamiljen, med skilda funktioner för mamma och pappa. Det innebär dock inte en patriarkal position (Johansson 2004), som också omfattar ett försörjningsansvar. Den handlar snarare om "deltidspappan", eller »den andre föräldern", som efter separation inte längre bor med sina barn (Andersen 2003, Berg \& Johansson 1999). En familjebildning där den traditionella uppdelningen mellan pappans och mammans roller kvarstår. Barnen lever större delen av sin tid med mamman, medan fädernas tid med barnen är mer begränsad. Men om bilden av deltidspappan, i statistik och forskning, speglar ett faderskap i kris, som antingen leder till förändring och utveckling eller till en förlorad kontakt, frammanas en annan bild i de homosexuella fädernas berättande. De positionerar sig i en alternativ berättelse. I dessa homosexuella fäders berättande - om sina barn, om relationen till mödrarna och om utformandet av föräldraskap i tre- eller fyrföräldrakonstellation, utmanas den heteronormativa grundbalk som genomsyrar såväl berättelsen om kärnfamiljen som berättelsen om deltidspappan. En heteronormativitet i vilken den heterosexuella tvåsamheten framställs som en självklar utgångspunkt för föräldraskap. I de berättelser som fokuserats ovan har barnen tillkommit i ett i högsta grad självvalt och reflexivt familjebildningsprojekt, i vilket fäderna från första stund varit medvetna om att familjen består av ett fler-än-tvåföräldraskap, i skilda hushåll. Här skymtar inga brustna illusioner. Därtill fanns också insikten om samhällets okunskap, misstänksamhet och ibland rena fientlighet mot det homosexuella föräldraskapet. Trots 
detta har dessa män valt att bli föräldrar, ett aktivt val som innebär att även om de i sitt berättande positionerar sig som anpassade till mödrarnas vilja och krav, uttrycker en "barnorienterad maskulinitet" (Bekkengen 2002). I den mening att man längtat efter barn, planerat för barn och givit utrymme för barn i sina liv.

Det förhållningssätt till faderskapet som formuleras som en anpassning till mamman präglas alltså av disparata diskurser om faderskap. Här återfinns både traditionella och nya sätt att positionera sig som pappa i en samhälleligt och kulturell kontext, i en blandning som utmanar den heteronormativitet som genomsyrar dominerande diskurser om föräldraskap.

\section{En med mamma likvärdig pappa}

Det andra förhållningssätt som visar sig i intervjuerna bygger till stora delar på att tala om sig själv som en pappa likvärdig och jämbördig med mamman. Här skapas en pappaidentitet som bygger på bilden av en delaktig förälder. Det kommer till uttryck $i$ åtta mäns berättande. Av dessa åtta män, är sex sammanboende eller partners, och dessa tre par delar faderskap med varandra. De övriga två är ensamstående som fäder, varav en av dem är sammanboende med en man som inte är delaktig i familjebildningsprojektet. Barnens ålder varierar mellan spädbarn och 13 år.

Ett karaktäristiskt drag är att relationen till barnen beskrivs med starkt känslomässiga toner. I excerpten nedan berättar Olle, en av två pappor till två barn, om det tillfälle när han och hans partner, tillsammans med det lesbiska par de delar föräldraskap med, formulerade ett s.k. barnabrev. ${ }^{9}$ Parallellt väver han in kommentarer om att på förhand inte förstå vad det innebar att få barn. Mikael, hans partner, beskriver hur deras ursprungliga idéer tonades ned och fick en annan innebörd när deras förstfödde dotter väl fanns där och behövde konkret omhändertagande och omsorg.

Olle

Samtidigt som jag personligen ibland kan skratta at en del av dom sakerna vi kom fram till... för dom är ju verkligen sprungna ur en icke erfarenhet av hur det är att ha barn (Mikael: Hmhm) dom känslomässiga omställningarna vad som händer $i$ en... att verkligen... värken när man inte fär träffa Ebba (dottern) att inte få sova med henne själv... att inte fà sina egna insomningsvanor... att inte kunna känna alla hennes bitar... vad hon tycker är roligt och pilla med.. vad hon blir glad av... vad som gör henne ledsen

I beskrivningen av vardagserfarenheter av att ha barn, som insomningsvanor, lekvanor osv., positionerar sig Olle som en

9 Inför bildandet av familj har flertalet familjer i studien valt att skriftligen formulera ett som de kallar "moraliskt kontrakt", där parternas rättigheter och skyldigheter uttrycks, och som alla sedan undertecknar. 
pappa, vars föräldraskap bygger på konkret omvårdnad och närhet till barnet. Olle talar om "dom känslomässiga omställningarna" liksom "värken" som följer av att inte träffa henne. Att som Olle framställa detta som viktigt och nödvändigt, liksom den smärta det innebär att inte få del av det, kan tolkas som ett sätt att positionera sig som känslomässigt nära dottern. Men här sker också en positionering i intervjun. Att framhäva sitt känslomässiga behov av barnen och intresse för barnets vardagliga liv, är ett sätt att presentera sig som en barnorienterad pappa.

Ett annat sätt att signalera en stark känslomässig relation till sitt barn framträder i Peters beskrivning nedan. Den följer direkt på en fråga om vilka nackdelar det finns med den familjeform man valt att skapa, varvid Peter kommenterar att det blir en splittrad familj och fortsätter:

Peter Vadjagser är det där... är saknaden... framför allt det är saknaden efter barnen när dom inte är här... självklart [...] när man har dom och dom är jobbiga och dom bråkar med varandra och kallar varandra för saker och så där... kan kännas herregud... vad jobbiga dom $\ddot{a r}$... men det är den där kärleken som man har från dom som...jaa... det är otroligt

Peter nämner "saknaden" efter barnen. Genom att samtidigt framhäva hur barn kan var besvärliga, inte minst när de är osams, blir budskapet om behov av och kärlek till barnen desto starkare. Barnen framställs som en betydelsefull och viktig del av livet, oavsett bråk och osämja. På detta sätt framhävs föräldraskapets existentiella dimensioner, där barn förknippas med frågor som rör livets mening. Det blir också tydligt i Bertils berättande.

Bertil Alltså mitt liv har ju blivit så fantastiskt mycket rikare sen jag fick barnen... (Intervjuare: $\mathrm{Hm}$ ) jag menar... leva som ensamstående bög... det innebär tyvärr väldigt mycket att man går ut och lever loppan och besöker barer och nattliv och... ja... ett väldigt mycket mer egocentriskt liv... och många gånger ytligare också (Intervjuare: $\mathrm{Hm}$ ) då mitt liv har ju fätt ett totalt annat innehåll då med både kärlek och ... ja... andligare också... djupare andligare värde... mycke mycke mycke mycket... det går inte och jämföra (Intervjuare: $\mathrm{Nej)} \mathrm{har} \mathrm{man} \mathrm{en} \mathrm{gång} \mathrm{varit}$ förälder kan man aldrig tänka bort hur var det (Intervjuare: Neej) hur skulle livet ha varit utan

Bertil redogör för hur hans liv förändrats av att skaffa barn, från ett regocentriskt liv", "ytligare" till ett liv idag vars innehåll definieras i termer av »kärlek" och "djupare andligare värde«. Bertil talar om sig själv som "förälder", något som han aldrig mer "kan tänka bort hur det var".

Det är ett förhållningssätt som också mejslas fram genom det sätt varpå infor- 
manterna talar om mammorna. Jan och Peter, i utdraget nedan, uppfattar att mammorna har sett sig som att de wvar nummer ett» som föräldrar. Det är något som samtidigt avvisas som oacceptabelt.

Peter Jag tror att nånstans att dom ändå tänkte sig att dom två var nummer ett på nåt vis

Jan Hmhm

Intervjuare Ochvarfanns du där?

Jan Och då var jag väl litet steget utanför och skulle finnas med på den bilden (Intervjuare: Ja... så) som pappa till det här barnet och umgänge och så där men... det var inte riktigt min syn påsaken

Peter Neej neej

I sin beskrivning tar Jan avstånd från vad han uppfattar som mammornas sätt att definiera hans roll "som pappa» med "umgänge». I direkt anslutning till vad som sägs ovan infogar intervjuaren en kommentar rörande pappans roll, varvid reaktionen från Jan blir skarp.

Intervjuare Utan du hade mycket mera tankar... mycket mera aktiv

Jan Ja...jagavskyrju det där pratet om aktiv och passiv pappa...jag avskyr och bli definierad över huvud taget som nånting annat än sompappa

Intervjuare Och hur är det... hur är en pappa? Vad är en familj och en pappa... en mamma?

Jan Ja... pappa är precis som mamma är mamma... hon behöver inte definiera sig som tre-kvarts-aktiv ellertvå-tredjedels-passiv eller nånting(Peter: Neej) hon är så självklar och det tyckerjagattjagär också

När Jan pratar om sig själv som pappa gör han det med termer och ord som tar formen av ett försvarstal för rätten att vara "självklar». I första inlägget använder han orden "utanför", "som pappa", "umgänge", när han beskriver hur han uppfattade att mammorna hade föreställt sig hans plats $i$ familjen. När intervjuaren i direkt anslutning till detta använder begreppet "aktiv" positionerar han sig mycket tydligt i intervjusamtalet, genom att klargöra att han "avskyr pratet om aktiv och passiv pappa". Denna korta interaktion mellan intervjuare och informant blir ett tydligt uttryck för ett identitetsskapande som pappa, där föreställningar om pappor som mer eller mindre aktiva, mer eller mindre en del av familjen, avvisas kraftfullt. Den positionering som synliggörs i båda excerpter ovan, dels på den första nivån när aktörerna i familjen och deras inbördes relationer tydliggörs, dels på den andra nivån, i själva intervjusamtalet, visar på ett förhållningssätt där papparollen framställs som lika "självklar" som mammas.

Detta förhållningssätt speglar en situation där flera föräldraparter gör anspråk på att vara likvärdiga som föräldrar. Om den ena parten inte accepteras av den andre som en jämbördig och delaktig förälder, uppstår en situation som leder till konflikt. Och berättelser om konflikter kan också sägas karaktärisera detta förhållningssätt. 


\section{Konflikter med mammorna}

Bengt, en pappa som delar föräldraskap med ett lesbiskt par till en liten dotter, formulerar sig kring vad han ser som homoföräldrarnas centrala konflikt. Bengt uttrycker sig med stor försiktighet, han trevar sig fram efter orden, till synes reflekterande, vilket antyder en medvetenhet om intervjusituationen.

Bengt Det är liksom det... som hela tiden är stötestenen och problematiskt och så... det... jaa... och det här med barnets homosexuella familjer [...] det där om sexualiteten och allt det där... är ju egentligen ganska ointressant $i$ sammanhanget va... ähm ... utan den ena stora grejen det är ju det här... hur fixar man till det här med vårdnad... vårdnad när det är olika familjekonstellationer med kanske tre eller flera personer eller personer som inte bor tillsammans (exemplifierar med namn ) utan jag skulle nog säga där... om man ser vad som framkallar diskussioner... så är det hela tiden... eller konflikter när det vart problem då... om jag känner... såär det ju hela tiden vårdnadsfrågan hur mycket skall hon (dottern) va hos mig och hur mycket ska hon vara hos dom

I slutmeningen sammanfattar han konfliktens kärna: »hur mycket skall hon va hos mig och hur mycket ska hon vara hos dom «. Bengt säger att vara en homofamilj är mindre svårt än att hantera vårdnadsfrågan. Han förskjuter frågan om barn $i$ homosexuella familjer, till frågan om barn med föräldrar som inte bor ihop. Bengt beskriver en situation där tiden med barnet blir en konstant förhandlingsfråga, som dels kräver mycket diskussioner, dels kan ge upphov till konflikter. Det finns anledning att tro att det lite långsamma och försiktiga sättet varpå Bengt redovisar dessa tankar visar att det är ett tydligt försök till omformulering av ett problem. Bengt, liksom övriga pappor här, berättar om hur han och mammorna har svårt att komma överens och hur han uppfattar att han inte får gehör för sin önskan att träffa sin dotter mer.

De konflikter som uppstår till följd av diskussioner om tiden med barnen, visar sig inte direkt vid barnens födelse. Att barnen bor med sina mödrar när de är spädbarn är inte omtvistat, utan framställs som självklart av alla de pappor som ingår i studien. Däremot när barnen börjar bli äldre, börjar gå själv och tala, då uttrycker papporna här hur deras önskan att spendera mer tid med barnen inte får gehör hos mammorna. Olle säger:

Olle

Vad jag $i$ dag med erfarenhet av att ha varit tillsammans med Ebba (dottern) under femton mainader nu... kan känna det är att... jag tror det är angeläget både för Ebba och för mig och Mikael att vi lite snabbare kommer till ett delat boende... vilket är målet för oss alla fyra... att Ebba skall ha ett 
delat boende i framtiden... och vi diskuterar nu alla fyra... eller rättare sagt borde diskutera alla fyra i gruppen det är ju hur planen för att komma dit ska se ut... och vilka tidsperspektiv vi pratar om... rent ut sagt... så är Mikael och jag ganska otåliga $i$ dag för att få ta en större aktiv del $i$ Ebbas vardag

I redogörelsen ovan beskriver Olle hur papporna önskar att de »lite snabbare kommer till ett delat boende". Men efter att först ha sagt att det är något wvi diskuterar nu alla fyra", så ändrar han ordvalet och säger "borde diskutera", vilket antyder att mammorna kanske inte är eniga med papporna i den frågan. Olle använder också uttrycket "rent ut sagt", innan han säger att "Mikael och jag ganska otåliga $i$ dag för att få ta en större aktiv del i Ebbas vardag", vilket underförstått signalerar deras uppfattning om ett motstånd från mammornas sida. Budskapet om mer tid med barnet ramas in med ett tydliggörande av problemet, liksom en relativt uttalad kritik av mammornas tveksamhet att bemöta pappornas önskan. De pappor som ger uttryck för detta förhållningssätt, där pappor framställs som likvärdiga mammor, är generellt mer öppet kritiska mot de mammor man delar föräldraskap med. Till skillnad från den stora försiktighet med vilken de pappor som anpassade sig till mammorna framförde sin önskan om mer tid med barnen.

Det förhållningssätt som beskrivits ovan präglas dock inte genomgående av berättelser om konflikter med och kritik av möd- rarna. Tvärtom, här berättas också om goda relationer till mammorna. Som t.ex. Oskar i utdraget nedan, som efter att ha givit uttryck för sin kritik av mammans sätt att inte vilja dela omsorg och fostran med papporna, säger:

Oskar

Men alltså nu är detta jättemycket problem vi drar upp... men jag tycker samtidigt också vi också måste betona hur bra det fungerar med barnen alltså... och hur nöjda vi egentligen är... alltså konstigt nog så är vi det... vi hör och ser ... och hör andra som har mycket svårare... där papporna inte fär tillgång till barnen till exempel där mammorna är väldigt mycket possessiva och skall själva ha barnen och papporna fär verkligen på nåder... här alltså Maja (mamma) ger ju oss med glädje barnen... hon vill att dom ska va hos oss... vi är viktiga för barnen... det vet hon... också att det är aldrig nåt problem... alltså det är jättebrapå det sättet

I redogörelsen klargör Oskar att det inte bara har varit problem och att de känner till andra pappor som har betydligt större problem än vad han och hans partner haft: "där mammorna är väldigt mycket possessiva och skall själva habarnen och papporna får verkligen på nåder «. Utdraget ovan kan dels ses som en positionering i berättelsen om familjen, där Oskars faderskap framställs som nära relaterat till mamman, i ett

Karin Zetterqvist Nelson: Att vara pappa i homofamiljer - berättelser... 
gemensamt projekt. På ett interaktionellt plan förmedlar Oskar i intervjun också en bild av sig själv som en medveten och öppen förälder, i en familjebildning som är möjlig att genomföra och leva i.

\section{Närfaderskap och moderskap likställs somföräldraskap}

Den pappaidentitet som skapas i det sätt varpå de åtta män som positionerar sig själva som likvärdiga mamman präglas av en barnorienterad maskulinitet (Bekkengen 2002), vilket också var karaktäristiskt för det förstnämnda förhållningssättet. Men här framträder denna barnorienterade maskulinitet med en starkare betoning av det känslomässiga behovet av att vara med sina barn och att vara pappa/förälder. Den "stora berättelsen" om kärnfamiljen, med ett faderskap som kvalitativt skilt från moderskap, är inte närvarande här. Istället framträder en berättelse om det likvärdiga föräldraskapet. Det är frikopplat från biologiskt kön i den betydelse att förmågan till den kärlek, omsorg, skydd och fostran barn behöver beskrivs inte som kvinnliga egenskaper. En diskursiv koppling mellan kvinnlighet-moderskap-primär vårdare upphävs, till förmån för ett sätt att tala om föräldraskap som relationellt utan att vara könsspecifikt (Golombok 2000, Parke 2004).

Thomas Johansson (2004) skriver om hur faderskap åstadkoms och görs via olika strategier och positioner; den patriarkala positionen, omvairdnadsmannen och queer positionen. Den position som kallas omvårdnadsmannen är tydlig i det förhållningssätt som beskrivits här. Konflikten med mödrarna, liksom kritiken av mammornas sätt att förhandla om barnen, kan i det perspektivet ses som en konsekvens av en situation där parterna är, eller eftersträvar att bli erkända som jämbördiga i förhandlingen om tid och rum med barnen. Här skymtar en igenkännbar berättelse om de specifika dilemman och problem som följer av heterosexuella pars separation och skilsmässa (Hydén \& Hydén 2002). Det är också vad en av informanterna uttrycker explicit; homofamiljernas stora problem är inte sexualiteten, utan frågan om att dela på tiden med barnen. Därmed framtonar också den berättelse som utmanar heteronormativiteten. Fast i en annan tappning än det sätt varpå fäder som valt att anpassa sig till mödrarna gör. Med Johanssons termer ser vi en queer position från vilken faderskapet mejslas fram, med anknytning till bilden av en omvårdnadsman. Fast inte i en jämställd heterosexuell tappning, utan snarare i riktning mot vad Johannson också benämner som ett "flexibelt föräldraskap" (s. 142). Bortom en traditionell genus- och sexualitetsordning.

\section{Konklusion}

I den här artikeln om regnbågspappor har jag diskuterat två sätt att förhålla sig till faderskap. Ett karaktäriseras av att papporna positionerar sig som anpassade till mammornas vilja. Dessa fäder beskriver hur relationen till barnen är uppbyggd kring de premisser mammorna ställt upp. Det är en positionering som också blir påtaglig i intervjusituationen. Den sparsamma kritik som riktas mot mammornas 
beslut är både inlindad och nedtonad. Ett andra förhållningssätt till faderskap framträder bland de pappor som positionerar sig som jämbördiga med mammorna. Det byggs också upp kring en tydlig betoning av barnens betydelse för de själva som pappor och föräldrar, både känslomässigt och existentiellt. Här formuleras önskningar om att träffa barnen mer. Relationen till mammorna beskrivs dock som mer konfliktfyllt, eftersom de sägs göra motstånd mot fädernas önskan. Det är en positionering som är påtaglig i intervjusituationen, i det att kritiken framförs mer öppet och oförbehållsamt. Dessa två olika sätt att positionera sig som pappa i regnbågsfamiljer skapar delvis men inte helt skilda faders- och föräldradiskurser. Båda utmanar en heteronormativitet och båda är uttryck för en barnorienterad maskulinitet. Skillnaden ligger i sättet att förhålla sig till föräldraskapets genusdimension.

Jag vill föreslå att den svenska familjeoch föräldrapolitiken, med stark betoning av dels biologiskt föräldraskap, dels vikten av en närvarande pappa, utgör en diskursiv fond mot vilken dessa homosexuella fäder utformar sitt faderskap. Å ena sidan har den öppnat upp för fäderna att tillsammans med de lesbiska mödrarna bli involverade som fäder i omsorgen och fostran av barnen (Ryan-Flood 2005). $\AA$ andra sidan utmanar dessa fäder samma familje- och föräldrapolitik, oavsett förhållningsätt, genom att rucka på den heteronormativi- tet som genomsyrar jämställdhetsdiskursen (Dahl 2005). Den aktiva och delaktiga pappan i regnbågsfamiljer lever inte i ett heterosexuellt förhållande med mamman. I det ena förhållningssättet tenderar papporna att förhålla sig mer anpassliga till en traditionell genusordning; mödrarna har tolkningsföreträde när det gäller utformning av vård och omsorg om barn. Medan det andra förhållningssättet utmanar föräldraskapets genusdimension, genom att tillskriva faderskapet likvärdig status som moderskapet. Dekonflikter och tvister som beskrivs kan i ett dylikt perspektiv ses som en reaktion på denna utmaning, där kvinnors företräde ifråga om barn och omsorg ifrågasätts, både i kraft av sina kroppar (de bär barnet under graviditen, eller lever samman med den kvinna som är gravid) och i en kulturellt dominerande moderskapsdiskurs (se t.ex. Hallden 1992). Föräldraskapets genusdimension blir därmed tydligare i regnbågsfamiljerna och måste förhandlas på ett sätt som inte blir så synligt i heterosexuella föräldrarelationer.

Papporna i den här studien ger uttryck för två sätt att utforma faderskap knutna till tid och plats. Vilka de situationer är som ger upphov till det ena eller andra, såsom barns ålder, boendesituation, fädernas relationer till varandra när de är två, social klass osv., är frågor som jag lämnar obesvarade men som öppnar för vidare forskning. 


\section{Referenser}

Andersen, Arnfinn (2003) Menn skaper rom for foreldreskap og families. Faderskapets betingelser i en heternormativ kultur. NTNU.

Anderssen Norman, Amlie Christine \& Ytteroy André (2002) »Outcomes for children with lesbian or gay parents. A review of studies from 1978-2000«. Scandinavian Journal of Psychology nr. 43, s. 335-351.

Armesto, Jorge (2002) "Developmental and Contextual Factors That Influence Gay Fathers' Parental Comptence: A Review of the Literature". Psychology of Men \& Masculinity vol 3 nr. 2, s. 67-78.

Bailey Michael, Bobrow David, Wolfe Marilyn \& Mikach Sarah (1995) "Sexual orientation of adult sons of gay fathersu. Developmental Psychology, vol. $31 \mathrm{nr}$. 1,s. 124-129.

Bamberg, Michael (2004) „Form and Functions of 'Slut Bashing' in Male Identity Constructions in 15-year-Olds». Human Development nr. 47, s. 331-354.

Barrett, Helen \& Tasker, Fiona (2001) „Growing up with gay parents: Views of 101 gay fathers on their sons' and daughters' experiences". Educational and Child Psychology vol. $18 \mathrm{nr}$ 1, s. 6277.

Bekkengen, Lisbeth (2002) Man fär välja - om föräldraskap och föräldraledighet $i$ arbetsliv och familjeliv. Liber: Malmö.

Berg, Lars-Erik \& Johansson, Thomas (1999) Den andre föräldern. Om deltidspappor och deras barn. Stockholm: Carlssons.

Bozett, Frederic (1980) "Gay Fathers: How and why they disclose their homosexuality to their children". Family Relations n r. 29, s. 173-179.

Bozett, Frederic (1988) "Social Control of Identity by Children of Gay Fathers". Western Journal of Nursing Research vol. 10 nr. 5, s. 550-565.

Bozett, Frederic (1993) „Gay Fathers: A Review of the Literature". in Linda Garnets \& Douglas Kimmel (Eds.), Psychological Perspectives on Lesbian and Gay Male Experiences. New York: Colombia University Press.

Bäck-Wiklund, Margareta (2003) „Familj och modernitet». i Margareta Bäck-Wiklund \&
Thomas Johannson (red) Nätverksfamiljen. Stockholm: Natur och Kultur.

Castells, Manuel (1997) Identitetens makt. Göteborg: Daidalos.

Crosbie-Burnett, Margaret \& Helmbrecht, Lawrence (1993) "A Descriptive Empirical Study of Gay Male Stepfamilies». Family Relations nr. 42, s. 256-262.

Dahl, Ulrika (2005) „Scener ur ett äktenskap: Jämställdhet och heteronormativitet». i Don Kulick (red.) Queersverige. Stockholm: Natur och kultur.

Donovan, Catherine (2000) „Who Needs a Father? Negotiating Biological Fatherhood in British Lesbian Families Using Self-Insemination?" Sexualities vol. 3 nr. 2, s. 149-164.

Dunne, Gillian (2000) "Opting into motherhood; 'That's our kind of constellation". Gender and Society vol. 14 nr. 1, s. 11-61.

Dunne, Gillian (2001) „The Lady Vanishes? Reflections on the Experiences of Married and Divorced Non-Heterosexual Fathersu. Sociological Research Online vol. 6, nr. 3, s. 1-16.

Giddens, Anthony (1995) Intimitetens omvandling; Sexualitet, kärlek och erotik i det moderna samhället. Nora: Nya Doxa.

Golombok, Susan (2000) Parenting. What really counts? London: Routledge.

Hagström, Charlotta (1999) Man blir pappa. Föräldraskap och maskulinitet i förändring. Lund: Nordic Academic Press.

Hallden, Gunilla (1992) Föräldrars tankar om barn. Stockholm: Carlssons.

Hydén, Margareta \& Hydén, Lars-Christer (2002) Samtal om den nya familjen och det eviga föräldrarskapet. Stockholm: Natur och kultur.

Johansson, Thomas (2004) Faderskapets omvandlingar: Frånvarons socialpsykologi. Göteborg: Daidalos.

Klint, Roger (2002) Göra pappa med barn. Den svenska pappapolitiken 1960-65. Umeå: Borea Bokförlag.

Kulick, Don (red.) (2005) Queersverige. Stockholm: Natur och kultur.

Larsson Sjöberg, Kristina (2000) Barndom i län- 
kade familjesystem. Om samhörighet och åtskillnad. Örebro Studies 19.

Mallon, Gerald P. (2004) Gay Men Choosing Parenthood. New York: Colombia University Press.

Nelson, Fiona (1996) Lesbian Motherhood. An Exploration of Canadian Lesbian Families. University of Toronto Press.

Parke, Ross D. (2004) „Development in the family." Annual Review of Psychology, vol. 55 s. 365-399

Plantin, Lars (2003) „Faderskap i retorik och praktik. Om 'nya' fäder i gamla strukturer". I Margareta Bäck-Wiklund \& Thomas Johansson (red) Nätverksfamiljen. Stockholm: Natur och kultur.

Ryan-Flood, Róisin (2005) „Contested Heteronormativities: Discourses of Fatherhood among Lesbian Parents in Sweden and Ireland."Sexualities vol. 8(2) s. 189-204.

SOU 2001:10. Barn i homosexuella familjer.

Stacey, Judith \& Biblarz, Timothy (2001) »(How)
Does The Sexual Orientation of Parents Matter? "American Sociological Review vol. 66, s. 159-183.

Touroni, Elena \& Coyle, Adrian (2002) „DecisionMaking in Planned Lesbian Parenting: An Interpretative Phenomenological Analysis». Journal of Community \& Applied Social Psychology nr. 12, s. 194-209.

Weeks Jeffrey, Heaphy Brian \& Donovan Catherine (2001) Families of Choice and Other Life Experiments: The Intimate Lives of Non-Heterosexuals. London: Routledge.

Wyers, Norma (1987) "Homosexuality in the Family: Lesbian and Gay Spouses». Social Work vol. 32 nr. 2, s. 143-148.

Zetterqvist Nelson, Karin (in press) "The Construction of an Open Time Dimension in Narratives about the Becoming of Lesbian and Gay Families: An Act of Resistance". Gay and Lesbian Issues and Psychology Review. (Special Issue: LG parenting).

\section{Summary}

\section{Being a father in a gay family: Narratives about children, mothers and family life}

The aim of this article is to discuss how fatherhood is constructed in twelve gay fathers' stories about how their family came into being. These informants took part in a broader study of lesbian and gay families carried out during 2002-2003. In a narrative analysis of how the informants position themselves, both in describing their family and in the interactional setting of the interview, two different ways of talking about themselves as fathers and their place in the family are discerned. One is displayed through the way the informants give preference to the mothers and comply with their will and wishes. The mothers are talked about as both special in terms of their motherhood, and as superior in respect to the care and custody of the children. As fathers they describe themselves as dependent upon the will of the mothers. Being with their children is largely dependent upon the conditions set up by the mothers. Parenthood is defined in terms of gender differences, where the superiority of motherhood is accepted as self-evident. At those moments in the interviews where a father disagrees with the mother's decision or will, any critical utterance is downplayed 
and expressed with great caution. This way of positioning themselves has similarities to heterosexual fathers, who, after a divorce, with visiting rights, become dependent upon the mother's will. However, there are also differences, related to the lack of former emotional and sexual relations between the parents. The relations between the gay fathers and lesbian mothers have from the beginning been defined in terms of parenthood, with the conditions concerning care and custody discussed from the start. However, the other way of positioning displays how gay fathers oppose a place in the family dependent upon the decision of the mothers. They claim to be parents on equal terms with the mothers, with not only visiting rights but also shared custody. In their stories their love for and need of their children is emphasized, and parenthood is articulated in terms of the meaning of life and existential discourse. The mothers' decisions are more openly criticized and motherhood is not considered as having a special meaning for the children. This way of positioning oneself as a parent on equal terms with the mothers has similarities to heterosexual fathers who claim shared custody after a divorce. A discourse of parenthood freed from biological gender is discerned, in which parental qualification is related to relational qualities rather than to parents' biological gender. 